\title{
Online Learning Challenges during Pandemic COVID-19 in Malaysian Higher Learning Institution
}

\author{
Nur Salina Ismail ${ }^{1, *}$, Nor Mazlina Abu Bakar², Sharifah Wajihah Wafa Syed Saadun Tarek Wafa ${ }^{3}$ \\ ${ }^{1}$ Centre of English Language, Faculty of Languages and Communication, Universiti Sultan Zainal Abidin, Gong Badak Campus, 21300 \\ Kuala Nerus, Terengganu, Malaysia \\ ${ }^{2}$ Centre of Management Sciences, Faculty of Business and Management, Universiti Sultan Zainal Abidin, Gong Badak Campus, 21300 \\ Kuala Nerus, Terengganu, Malaysia \\ ${ }^{3}$ School of Nutrition and Dietetics, Faculty of Health Sciences, Universiti Sultan Zainal Abidin, Gong Badak Campus, 21300 Kuala \\ Nerus, Terengganu, Malaysia
}

Received September 14, 2020; Revised October 25, 2020; Accepted November 25, 2020

\section{Cite This Paper in the following Citation Styles}

(a): [1] Nur Salina Ismail, Nor Mazlina Abu Bakar, Sharifah Wajihah Wafa Syed Saadun Tarek Wafa , "Online Learning Challenges during Pandemic COVID-19 in Malaysian Higher Learning Institution," Universal Journal of Educational Research, Vol. 8, No. 12, pp. 7151 - 7159, 2020. DOI: 10.13189/ujer.2020.081282.

(b): Nur Salina Ismail, Nor Mazlina Abu Bakar, Sharifah Wajihah Wafa Syed Saadun Tarek Wafa (2020). Online Learning Challenges during Pandemic COVID-19 in Malaysian Higher Learning Institution. Universal Journal of Educational Research, 8(12), 7151 - 7159. DOI: 10.13189/ujer.2020.081282.

Copyright $\odot 2020$ by authors, all rights reserved. Authors agree that this article remains permanently open access under the terms of the Creative Commons Attribution License 4.0 International License

\begin{abstract}
Since the announcement of the movement control order (MCO) to help curb the spread of COVID-19 virus, education institutions across the nation have taken great measures to ensure that their students can continue learning through digital means. Hence, academicians and students have to start setting their mind that they have to adapt new learning processes that do not allow physical meetings. This has raised concerns on how students are to cope with this new online learning environment since they come from different socioeconomic backgrounds. Therefore, the aim of this study is to identify the challenges faced by university students when implementing online learning during pandemic COVID-19. A preliminary online study is conducted among 542 students in Universiti Sultan Zainal Abidin Malaysia (UniSZA) to investigate the challenges and problems they may face adapting with the new "norm". The findings indicated that the majority of the students are not ready for online learning as the main challenge faced is low internet access to enable them for online learning. The findings from this study have benefitted the university management in making prompt and effective decisions concerning the implementation of remote learning during the pandemic. In order to get the full benefit of online learning, a concerted effort is needed from many as to provide this structure and go beyond replicating a physical class/lecture.
\end{abstract}

Keywords Online Learning, Higher Institution, Challenges, University Students, COVID-19

\section{Introduction}

In Malaysia, there are currently 20 public universities and 41 private universities with enrolment of more than 1.2 million students [1]. Abundant resources are invested by the Malaysian Ministry of Higher Education (MOHE) with aims to develop a holistic individual that is intellectually, emotionally, spiritually, and physically balanced based on a firm belief and devotion to God [2]. In maintaining those constructs, the 11th Malaysian Plan encapsulates one of the main focus in education which is to raise the quality of education system for better student outcomes and institutional excellence. Besides conventional methods; teacher-student-classroom method of learning, learning space is now enhanced with online learning to keep pace in an increasingly competitive global education and be able to benchmark itself against the world-leading universities.

Online learning has its origin in what was traditionally known as distance education [3]. Today, many providers of distance education have become fully online or known as remote learning where all teaching and learning materials 
are made available to students online. The market of remote learning is already rapidly growing at US\$18.66 billion investment in 2019 with overall revenue projected at US\$350 Billion by 2025 [4]. The rapid advancement of new technologies has dramatically required the higher education institutions (HEIs) to provide online teaching and learning platforms in universities campuses through blended learning (BL) which combines concepts from both online learning and the face-to-face learning environment $[3,5]$. Besides having the normal classroom learning session, the concept of BL is well accepted by students due to its easy accessibility and effectiveness [6, 7, 8, 9, 10, 11]. Students can easily access their learning materials, participate in any online learning activities and forum, and sit for online assessments through Learning Management Systems (LMS) such as Moodle provided by their universities [12, 13]. The online teaching and learning activities are carried out efficiently with good and free Wi-Fi access provided by the universities when the sessions are conducted on campus. Besides, online learning sessions can be more of an advantage for both lecturers and students where they can monitor their learning assessments and join learning sessions such as group discussions and forums [14]. The main challenges for a successful online learning to take place is lack of training, facilities and infrastructure, students' preparation and learning tools [15]. Thus, adequate facilities must be provided for online learning to be effectively successful [16]. Students must have strong self-discipline in time management since there is no face-to-face interaction from instructors. Instructors must also undergo adequate training to develop suitable learning materials for the students [17]. Nonetheless, the need for online learning has increased due to its impressive features: capability to reach global audiences [18], and its unique functionality [11], accessibility [9] and flexibility [19]. The online learning is believed to be one of a complementary means not only to support conventional classroom learning, but also to instill the idea of lifelong learning [20].

In March 2020, the world was shaken by the declaration of COVID-19 as a global pandemic by the World Health Organization (WHO) as the infectious disease rapidly spread outside China, infecting and claiming millions of lives [21]. Countries including Malaysia have taken up decisive actions to mitigate the spread of the virus to a full-blown pandemic [21], resulting in schools and universities shutting all across the world forcing people to stay home. This pandemic has suddenly transformed the landscape of learning and teaching around the world. Online learning is seen as the only available option to replace conventional teaching with many benefits in effectiveness [22, 23]. The dynamic and innovative online learning environments enable students to have a meaningful learning experience $[24,25]$ and become the future of education [24]. Hence, universities in Malaysia have moved their classes online to ensure continuity to the teaching and learning process and minimize the spread of infection. Early precautions have been taken by allowing all public universities to have their own autonomy in exercising remote online learning to contain the spread. All academicians and institutions are now challenged with minimizing the impact on students. The main concern is to ensure all students receive education online of the same quality as conventional learning sessions when learning is done remotely.

Universiti Sultan Zainal Abidin (UniSZA) is one of the public universities in Malaysia, also faces some challenges related to online learning since this is the first time ever that the learning session will go fully online. The university is located in the east coast of Malaysia, comprising 10 faculties with 8961 students from different socio-economic backgrounds. Thus, it is important to find out basic information from the students such as identifying their problems so as to ensure remote learning can be executed effectively and efficiently. This study is carried out to gather information on students' readiness towards online learning practices in Malaysia higher learning institutions specifically at UniSZA amidst the COVID-19 pandemic; looking into some points of concerns and the challenges faced by students involved. Most importantly, while the digital divide becomes the issue, the focal point is assuring no student is left behind in learning.

The next section describes the methodology involved in the study which includes design of the study, participants and data collection. An online survey is conducted among UniSZA students to provide some insights into the study. Section 3 discusses the results obtained from the survey and Section 4 concludes.

\section{Materials and Methods}

\section{Study Design}

This study used an online survey carried out from March 2020 to April 2020 in Universiti Sultan Zainal Abidin (UniSZA), Terengganu, Malaysia. The survey is conducted to gather information on students' readiness towards online learning during the pandemic. Besides, the survey intends to examine the availability of IT equipment that enables them for online learning and solicit students' opinion on other challenges they might face.

\section{Participants}

Student population in the Faculty of Business and Management, UniSZA consists of 1,932 students enrolling in diploma or undergraduate programs for the session 2019/2020. The faculty offers four (4) bachelor programs and seven (7) diploma programs and is the second biggest faculty in UniSZA. This study used a sample of 542 students which is conveniently selected from the faculty. Detailed demographic profiling of the participants can be found in Table 1. 


\section{Data collection}

The online survey is conveniently distributed among the participants via google form with related questions on demographic data which covers gender, state, owning smartphones and computers and internet access. The survey also includes students' opinions on online learning during the pandemic and other challenges faced when online learning takes place.

\section{Data Analysis}

Results of descriptive statistics are presented as frequencies and percentages to understand the challenges faced by the students in which it would provide some insights for effective online teaching and learning sessions during the pandemic.

\section{Results}

Table 1 shows the demographic profiles of the participants involved in the survey. A total of 542 students representing $28.1 \%$ of the total students at the Faculty of Business and Management took part in answering the online survey.

Table 1. Demographic Profile of Participants

\begin{tabular}{|c|c|c|}
\hline & Frequency & $\mathbf{\%}$ \\
\hline Program & & \\
Diploma & 215 & 39.7 \\
Bachelor Degree & 327 & 60.3 \\
\hline Gender & & \\
Female & 395 & 72.9 \\
Male & 147 & 27.1 \\
\hline State & & \\
Selangor and Klang Valley & 93 & 17.2 \\
Northern & 90 & 16.6 \\
Southern & 88 & 16.2 \\
East Coast & 264 & 48.7 \\
Sabah \& Sarawak & 7 & 1.3 \\
\hline
\end{tabular}

The survey includes participants from both the bachelor degree programs (60.3\%) and diploma programs (39.7\%). The majority of students in UniSZA are female students which is translated by the survey whereby out of the total participants, 395 participants (72.9\%) are female with the remaining 147 participants (27.1\%) are male. The participants come from different parts of states in Malaysia with $48 \%$ of the participants are from the East Coast, $17.2 \%$ from Selangor and Klang Valley. $16.6 \%$ and $16.2 \%$ respectively are from Northern and Southern states of peninsular Malaysia. Only a small percentage of the participants is from Sabah and Sarawak (1.3\%).

Table 2 shows the results of a survey on student's readiness towards online learning. It can be seen that the vast majority of the participants (93.9\%) stated that they are not ready for online learning. Meanwhile only 6.1\% stated otherwise. The high state of unreadiness may be due to some factors which are elaborated in Table 3.

Table 2. Student's Readiness Towards Online Learning

\begin{tabular}{|c|c|c|}
\hline & Frequency & $\%$ \\
\hline $\begin{array}{c}\text { Are you ready for online learning? } \\
\text { Yes }\end{array}$ & $\mathrm{Wi}-\mathrm{Fi}$ & \\
No & 33 & 6.1 \\
& 509 & 93.9 \\
\hline
\end{tabular}

The participants of the survey are encouraged to state their opinions on what are the challenges that they might face while doing their online learning and the results are stipulated in Table 3. The majority of the participants (79.3\%) indicated that they might face internet problems; either low internet speed or no Wi-Fi connection at all. The participants (8.9\%) also admitted that they will face technical problems from lack of IT equipment especially the laptop or computer. A high percentage of the participants (14.4\%) also highlighted that they have insufficient reading references/materials. More importantly, $8.1 \%$ of the participants stated their worry on the effectiveness of the online method. Other participants pointed out family problems, lack of IT skills, health issues and also non-conducive learning environment as their main concerns in the hindrance of online learning.

Table 3. Challenges of Online Learning

\begin{tabular}{|c|c|c|}
\hline Challenges & No of Students & $\%$ \\
\hline $\begin{array}{l}\text { Internet problems } \\
\text { - } \quad \text { Low Internet Speed } \\
\text { No Wi-Fi connection }\end{array}$ & 430 & 79.3 \\
\hline $\begin{array}{l}\text { Technical problems } \\
\text { - } \quad \text { No laptop or computer }\end{array}$ & 48 & 8.9 \\
\hline Learning references/materials & 78 & 14.4 \\
\hline Worries on Online Learning & 35 & 8.1 \\
\hline $\begin{array}{ll} & \text { Miscellaneous problems } \\
\text { - } & \text { Lack of IT skill } \\
\text { - } & \text { Family problem } \\
\text { - } & \text { Health issues } \\
\text { - } & \text { Non-conducive environment }\end{array}$ & 38 & 8.8 \\
\hline
\end{tabular}

A few of these factors have emerged as more persistent and more frequently addressed than others. To further illustrate the challenges voiced out by the participants, the excerpts of the comments are presented in the following tables with remarks to further support the findings. As can be seen from Table 4, the main access-issue is not that of having a computer but that of the internet connectivity. It is usually the speed of the connection that is the limiting factor and with the low internet connection hinders the online learning session. 
Table 4. Illustrative Quotations on Internet Problems

\begin{tabular}{|c|c|}
\hline Challenges & Illustrative Quotations \\
\hline \multirow{6}{*}{$\begin{array}{l}\text { Internet } \\
\text { problem }\end{array}$} & $\begin{array}{l}\text { "Limited internet access in rural areas, network coverage is also not strong enough to access most of the time. Worried if during } \\
\text { online class I cannot access the internet." }\end{array}$ \\
\hline & $\begin{array}{l}\text { "Based on my answer above, I am not ready for online learning because in my place of residence, I have difficulty surfing the } \\
\text { internet, and it is difficult to communicate with any party online, moreover, I ask help from my friend to fill out this form, I } \\
\text { apologize if my difficulties affect your planning for online learning." }\end{array}$ \\
\hline & $\begin{array}{l}\text { "At home I do not have Wi-Fi, if there is online learning I have to buy data to get the internet. My telco offers internet data that } \\
\text { is less affordable and short time for the internet data, it is not worth it for me to buy the internet data. In my residential park area, } \\
\text { the internet line is quite slow.” }\end{array}$ \\
\hline & $\begin{array}{l}\text { "My home internet is very slow ... and the line here is very limited .. so it is very difficult for me to access the student portal or to } \\
\text { take online tests.” }\end{array}$ \\
\hline & $\begin{array}{l}\text { "The area of my house is located in the rural area, so it is quite difficult for me to get a high speed internet line. This makes it } \\
\text { difficult for me to access the university’s online learning platform and send the assignment.” }\end{array}$ \\
\hline & $\begin{array}{l}\text { "My house is at the end of the village, it is impossible for me to stay there during the online classes conducted and the internet } \\
\text { network here is not satisfactory." }\end{array}$ \\
\hline
\end{tabular}

Some parts of Malaysia experience poor internet connectivity due to geographical area. Not only that, the comparatively sluggish internet speed during the MCO is largely due to high usage and also infrastructure issue [26]. Based on the Malaysian Communications and Multimedia Commission (MCMC) Industry Report 2018 report, Malaysia moved up from the 32nd in the world from 56th in 2017 which is considered a commendable improvement. In 2019, the Ministry of Communications and Multimedia's National Ferberization and Connectivity Plan (NFCP) 2019-2023 was finally unveiled in September, upgrading Internet speed to gigabit level in selected industrial areas by 2020 [27]. Another plan is to widen fiber networks coverage to $70 \%$ of schools, hospitals, libraries, police stations and post offices by 2022. The university has held a series of workshops introducing platforms that can be applied by the academicians to be used for their teaching and learning classes; synchronous and asynchronous types.

It is crucial to understand the participants' worry on online learning in a more explicit way so that their views and opinions can be put forward for the respective authority to take charge upon as shown in Table 5.
Table 5. Illustrative Quotations on Worries on Online Learning

\begin{tabular}{|c|c|}
\hline Challenges & Illustrative Quotations \\
\hline \multirow{6}{*}{$\begin{array}{l}\text { Worry on } \\
\text { online } \\
\text { learning }\end{array}$} & $\begin{array}{l}\text { "In my opinion, even in class it is difficult to } \\
\text { understand one subject at a time, what more if it is } \\
\text { conducted online.. And I am a 'slow learner'." }\end{array}$ \\
\hline & $\begin{array}{c}\text { "I am not ready for online learning because I know } \\
\text { how my focus level is \& } \mathrm{i} \text { am worried if the learning is } \\
\text { not effective with me. but if there is, I am okay." }\end{array}$ \\
\hline & $\begin{array}{c}\text { "I'm ready, it just feels like it's not very effective to } \\
\text { study online, because even in class I don't focus, let } \\
\text { alone online. :( But I always have to be eager to finish } \\
\text { this diploma. Insha'Allah.” }\end{array}$ \\
\hline & $\begin{array}{l}\text { "difficult to discuss online. slow internet and I think } \\
\text { talking face to face is easier." }\end{array}$ \\
\hline & $\begin{array}{l}\text { "This is because online learning causes students to not } \\
\text { be able to focus } 100 \% \text {, especially in WhatsApp..this } \\
\text { causes the learning process to be chaotic due to the } \\
\text { message from lecture and students (occur) at the same } \\
\text { time..learning will also be difficult to understand } \\
\text { because there are no tutorials from lecture...a session to } \\
\text { ask questions will also be difficult .." }\end{array}$ \\
\hline & $\begin{array}{c}\text { "Still in trauma and anxiety regarding COVID-19. The } \\
\text { Internet in residential areas is slow for online } \\
\text { learning." }\end{array}$ \\
\hline
\end{tabular}


Many students express their uneasiness and worries over the idea of implementing online learning. They stated the feeling of unreadiness for online learning due to physical distancing requirements as all teaching and learning activities are shifted from traditional classroom meetings to distance learning either online or offline, utilizing electronic equipment (e-learning). The participants professed the emotional state of grappling with e-learning because of inadequate equipment and unconducive environments.

From the illustrations on the learning environment, the participants in Table 6 indicated a non-conducive environment, lack of IT skill and financial problems are also parts of the challenges for online learning. A high percentage of students at the faculty comes from low income group families and live in low cost housing areas with small rooms that they share with other siblings. Some families even live together with their married children. They also may face financial constraints to allocate for IT equipment and internet data purchase. Thus, the university provide an allowance to support internet data. The government also provides 1GB free data for every citizen. Friendly user learning platforms are also to be integrated to make online learning accessible and less scary to every student and instructor [14], [3].

Table 6. Illustrative Quotations on Learning Environment

\begin{tabular}{|c|c|}
\hline Challenges & \multicolumn{1}{c|}{ Illustrative Quotations } \\
\hline \multirow{2}{*}{$\begin{array}{c}\text { Non-conducive } \\
\text { environment }\end{array}$} & $\begin{array}{c}\text { "There are students who cannot study online at } \\
\text { home due to the fact that the siblings are still } \\
\text { small and the house space is small and there is } \\
\text { no special place to study. Want to study outside, } \\
\text { not allowed as the government's Movement } \\
\text { Control Order (MCO) which prevents them } \\
\text { from leaving the house." }\end{array}$ \\
\cline { 2 - 2 } & $\begin{array}{c}\text { "I don't mind online learning. But I want to } \\
\text { apologize. Sometimes my housing area (flats) is } \\
\text { a little noisy. }\end{array}$ \\
\hline Lack of skill & "I'm scared because I'm not good at using IT" \\
\hline $\begin{array}{c}\text { Financial } \\
\text { problem }\end{array}$ & $\begin{array}{c}\text { "Financial problem, that is, I need to subscribe } \\
\text { to the internet with the big data I am now using } \\
\text { basic internet." }\end{array}$ \\
\hline
\end{tabular}

\section{Discussion}

Based on the feedback from the participants on the readiness for online learning, the overwhelming majority of the participants asserted that they are not ready for it. The interpretation of data collected through the survey reflects an inclination of the participants' unreadiness due to the challenges feared by them. The findings are supported by another study [28]. Students are found to experience the Fear of Missing Out (FOMO) syndrome [1]. Responses and comments by the participants bring the following remarks:
1. Generally, students have access to a computer for their studies. The main concern of the challenge is heavily pointed to the poor internet connection experienced by the participants in their areas. This is consistent with the study conducted on browsing internet during MCO [29]. The infrastructural problems concerning those living in rural areas mainly refer to the internet not being available and bandwidth problems. Low internet speed is experienced by many in every part of the country during MCO due to the heavy usage of the internet.

2. Lacking learning references and materials becomes a worry too since they are used to hardcopy references from libraries and handouts by their lecturers. It could be because students are highly dependent on face to face contact with lecturers for any academic related matters [28] and their inexperience in distance learning [30], hence they need physical meeting.

3. Another area of concern is worries on online learning; they express their uneasiness that they cannot catch up with the online learning session as they prefer face-to-face mode. This is proven in a study by [2] that students need instant feedback and immediate response during learning. Besides, they worry they cannot fully understand learning content conducted via online. They also convey their restlessness towards having difficulties for group discussion. This finding is consistent with other few studies on online learning difficulties [31]. Other worry professed is on internet speed that will hinder them from downloading contents, taking quiz/test and etc.

4. Furthermore, the restlessness over a non-conducive environment which prevents them from engaging in an online learning session. This finding is supported in a few studies (example see [20]) which also show the same instances faced in Pakistan. Most of the students come from low income family backgrounds. They live in a small house with small siblings whereby some do not have their own rooms or private space for a conducive online learning space as suggested by [4]. Due to some family problem, even health issues could also hinder the participants from taking part in online classes.

5. Participants indicated the challenge of lacking in IT skill. There are still many students in the university setting who lack the basic skills and experience needed to be able to support themselves from a technology perspective in online settings. This claim is supported by [32] which also found that digital divide happens among students. Having this challenge of IT incompetency leads to internet anxiety hence will interrupt the online learning $[18$, 22].

6. With the challenges on online learning during pandemic outlined, the university management must look into these problems and take necessary measures 
to avoid any student being left out as has been suggested in a study [33].

\section{Recommendations on Critical Success Factors for Online Learning}

\section{Ensuring Reliable Network Infrastructure}

Reliable network infrastructure is crucial to support and maintain the quality of online learning. It has become a major issue across nations on internet accessibility among students who live in remote areas thus unable to participate in digital learning [18]. These underprivileged students will face difficulties to have video conferencing discussion among lecturers and friends and also to download learning resources. This requires the network infrastructure to be upgraded and strengthened nationally to support more than a million students accessing the internet at the same time since the quality of online learning is heavily dependent on the reliability of the digital access. One of the strategies is by mobilizing all major telecommunications (telco) service providers to boost their internet services especially for the under-served regions. Furthermore, universities must increase their server bandwidth to avoid uninterrupted online teaching and learning activities on their LMS platforms.

On another note, there is a gap in education due to different socioeconomic backgrounds [9]. The underprivileged students will be at the loss end during online classes due to financial matters especially in the cost of digital devices and data plans. To minimize such inequality in education, there should be a decrease in the access cost and quality of access in all countries must be enhanced to widen the digital divide.

\section{Utilizing Friendly Learning Tools}

It is very important to consider the convenience of learning tools that fit the learning environment $[17,34,15]$. Students will benefit from the learning process when they are able to find and process information [13], respond to their understanding [18] and thus reflect on their own learning using effective learning tools.

These user-friendly tools can be of advantage for both academicians and students; to produce, manage and obtain resources, and actively participate in learning activities [16, 35]. Academicians especially can have a variety of options to select learning option tools to have suitable and smooth online teaching and learning sessions that cater for different functions. Some of the effectively identified learning tools for learning are tools for resources producing, synchronous live teaching, asynchronous teaching, self-regulated learning, knowledge construction, and for resources and class management [10]. Some examples of learning tools include:

1) Tools for resources producing - recording software, Screen capture software, The software of video production, PowerPoint and WPS in Windows, Keynote in IOS system.

2) Tools for synchronous live teaching - All types of live streaming software, including software on interactive teaching, remote office, online course.

3) Tools for asynchronous teaching - All kinds of online teaching platforms for example Google Classroom as well as those launched by universities and enterprises -MOOC, Moodle.

\section{Adopting Suitable Digital Learning Resources}

Generally, digital learning resource refers to course related materials that support to achieve course learning objectives or outcomes. This form of resource is digitally formatted as to support the online teaching and learning. The instructors do not have to fully construct their own digital resources, but they need to know where to locate and acquire the information on how to integrate the materials as valuable and reliable sources of course content [5]. Some of the highly recommended digital learning resources are Massive Open Online Courses (MOOCs), e-books, simulations, models, graphics, animations, quizzes, games, and e-notes [1, 36, 12, 37, 38].

\section{Facilitating Effective Online Teaching and Learning}

One of the many challenges engaging online learning is compromising common learning time between instructors and students who are at different locations. Other challenges may arise when students might encounter internet access so they have to opt for asynchronous video conference. Due to such uncompromised common time, students tend to spend more hours on screen to comprehend the learning session independently. Thus, learning must be conducted effectively to avoid exhaustion, promote engagement $[12,24]$. Researchers at the University of Peking found that the most effective online sessions should last between 15 to 30 minutes only. This time span is to guarantee students to be more engaged, energetic and stay focused during the learning process.

\section{Providing Supports and Services for Lecturers and Students}

One key element to ensure quality online education is having effective support services [35]. Such support services must be extended to both academicians and students as to maintain their motivation for online learning [39]. Due to the global pandemic, and a drastic shift to fully online learning may cause a spark of uncertainty and ambivalence when dealing with technology. Support systems can be further collaborated with other bodies such as with the government, schools, enterprises, families, society, and etc. [40].

Online learning can actually be as effective as face-to-face education but universities need to upskill their staff to deliver online education effectively and efficiently. [41] Without intensive training on how to deliver effective 
online classes, they might see many students might easily disengage and drop out early. A lack of skill and experience among academicians particularly in online course design and pedagogy impacted negatively on student learning and engagement [42].

Effective faculty leadership is an important form of support services because faculties are the main stakeholders in the university who are committed to the core academic values. The role of leadership management plays a vital role during the critical time as they need to recognize the professional burden placed on faculty and staff during a personally stressful time. Besides giving motivation and encouragement, it is crucial to seek what they need and set realistic expectations [43]. In relation to support service for online teaching, all instructors must be provided with comprehensive guidelines on working remotely. The faculties too must be proactive in providing special support both for staff and students who are obliged to use technology during the pandemic.

\section{Conclusion}

COVID-19 outbreak has changed all facets of humanity; economics, social and education. This unexpected pandemic situation has changed the education landscape in Malaysia and gives significant impact on both the educators and the students. Students from low income families are likely to suffer more and are not physically and mentally prepared for the changes in teaching delivery via online learning. Online learning is very dependent on internet access and it is very challenging. This paper has discussed major challenges for online learning faced by the students as online learning is to be in full implementation in the university. Internet connectivity, worry on online learning, non-conducive learning environment and lack of technology skills are some of the major challenges. There are clear indications on students' unpreparedness for online learning with the comprehensible challenges outlined by the participants.

Apart from having conventional classroom settings, online learning is now becoming a full force means of teaching and learning method. Nevertheless, the effectiveness of online learning varies amongst age groups and this has been a challenge to all in accepting the new normal. In order to get the full benefit of online learning, a concerted effort is needed from many as to provide this structure and go beyond replicating a physical class/lecture. Many solutions for education are proposed that could bring much needed innovation. Furthermore, the findings from the present study have benefitted the university management in making prompt and effective decisions concerning the implementation of remote learning during the pandemic. Future research is highly needed to deepen the analysis of these challenges on online learning.

\section{Acknowledgements}

The authors would like to thank all UniSZA students and staff for helping in the recruitment and data collection process.

\section{REFERENCES}

[1] Statistik Pendidikan Tinggi, Malaysian Ministry of Higher Education, 2019.

[2] Littlefield, J., "The difference between synchronous and asynchronous distance learning”, 2018. Retrieved from https://www.thoughtco.com/synchronous-distance-learningasynchronous-distance-learning-1097959

[3] Hassan, H., I. M. Tahir, "Lecturers' Perspectives on Using KeLiP as an E-Learning Tool”, Information Management and Business Review, 2(5), pp. 203-215, 2011.

[4] Wains, S. I., W. Mahmood, "Integrating M-Learning with E-Learning", Proceedings of the 9th ACM SIGITE Conference on Information Technology Education, pp. 31-38, 2008.

[5] Mat Hassan, N., Daud, N., Mohd Yusoff, H., Mukhali, H. B., S. N. Juhari, "Enhancing Reflective Writing through E-Learning in Undergraduate”, International Journal of Academic Research in Progressive Education and Development, Vol. 6, No. 3, 2017.

[6] Agrawal, V., Agrawal, A., S. Agarwal, "Assessment of Factors for E-Learning: An Empirical Investigation", Industrial and Commercial Training, Vol. 48 No. 8, pp. 409415, 2016. DOI: 10.1108/ICT-03-2016-0015

[7] Dziuban, C., Graham, C. R., P. D. Moskal, "Blended Learning: The New Normal and Emerging Technologies”. International Journal of Educational Technology in Higher Education, 15, 3, pp. 1-16, 2018. DOI: 10.1186/s41239-017-0087-5

[8] Haryani, H., Wan Faezah, A., A. R. Nor Aini, "The Adoption of Blended Learning Among Malaysian Academicians", Procedia- Social and Behavioural Sciences, 67, pp. 175-181, 2012. https://doi.org/10.1016/j.sbspro. 2012.11.318

[9] Kintu, M.J., Zhu, C., E. Kagambe, "Blended Learning Effectiveness: The Relationship Between Student Characteristics, Design Features and Outcomes”. International Journal of Educational Technology in Higher Education, Vol.14, No. 7, pp. 2-20. doi: 10.1186/s41239-017-0043-4.

[10] Liao, H. L., H. P. Lu, "The Role of Experience and Innovation Characteristics in the Adoption and Continued Use of E-Learning Websites”, Computers \& Education, Vol. 51, No. 4, pp. 1405-1416, 2008.

[11] Picciano, A. G., "Blending with Purpose: The Multimodal Model”, Journal of Asynchronous Learning Networks, Vol. 13, No. 1, pp. 7-18, 2009. http://dx.doi.org/10.24059/olj.v1 3i1.1673. 
[12] Kerimbayev, N., Kultan, J., Abdykarimova, S., A. Akramova, "LMS Moodle: Distance International Education in Cooperation of Higher Education Institutions of Different Countries”, Education and Information Technologies, Vol. 22, No. 5, pp. 2125-2139. 2017.

[13] Oh, E. G., Huang, W. H. D., Mehdiabadi, A. H., B. Ju, "Facilitating Critical Thinking in Asynchronous Online Discussion: Comparison between Peer-and Instructor-Redirection”, Journal of Computing in Higher Education, Vol. 30, No. 3, pp. 489-509, 2018. https://doi.org/10.1007/s12528-018-9180-6.

[14] Abdullahi, A., Mohmad Rouyan, N., Mohd Noor, S. S., I. Bashir, "The Application of Web 2.0 Tools to Determine Receptive Skills among Malay Learners af Arabic Language at The Universiti Sultan Zainal Abidin (UniSZA)", e-Academia Journal, Vol. 7, 2018. doi: https://doi.org /10.24191/e-aj.v7iSI-TeMIC18.5379

[15] Munezero, M., Irura, M., Kirongo, B., Etiegni, L., J. Suhonen, "Challenges and Solutions to Providing Online Courses in Kenya: A Lecturer's Perspective at a Kenyan University”, The Online Journal of Distance Education and E-Learning, Vol. 4, No. 1, pp. 1-14, 2016.

[16] Ismail N. A., Abd Wahid, et. al, "The Challenges of Industrial Revolution (IR) 4.0 towards the Teacher's Self-Efficacy”, Journal of Physics: Conference Series, IOP Publishing, 2020. doi:10.1088/1742-6596/1529/4/042062

[17] Kumar, K.L., R. Owston, "Evaluating E-Learning Accessibility by Automated and Student-Centered Methods". Educational Technology Research and Development, Vol. 64, No. 2, pp. 263-283, 2016. https://doi.org/10.1007/s1142 3-015-9413-6

[18] Paul, N., M. Glassman, "Relationship between Internet Self-Efficacy and Internet Anxiety: A Nuanced Approach to Understanding the Connection”, Australasian Journal of Educational Technology, Vol. 33, No. 4, 2017. https://doi.org/10.14742/ajet.2791

[19] Gilbert, B. “Online Learning Revealing the Benefits and Challenges”, Education Masters, Paper 303, 2015

[20] Adnan, M., K. Anwar, "Online Learning Amid the COVID-19 Pandemic: Students' Perspectives”, Journal of Pedagogical Sociology and Psychology, Vol. 2, Issue 1, 2020 .

[21] World Health Organization, "Considerations in adjusting public health and social measures in the context of COVID-19: interim guidance”, 2020.

[22] Hsiao, B., Zhu, Y-Q, L-Y. Chen, "Untangling the Relationship between Internet Anxiety and Internet Identification in Students: The Role of Internet Self-Efficacy”, Information Research, Vol. 22, No. 2, Paper 753, 2017

[23] Kirkwood, A., L. Price, “Technology-Enhanced Learning and Teaching in Higher Education: What Is 'Enhanced' and How Do We Know? A Critical Literature Review. Learning, Media and Technology, Vol. 39, No. 1, pp. 6-36, 2014. doi:10.1080/17439884.2013.770404

[24] Rapanta, C., Botturi, L., P. Goodyear, “Online University Teaching During and After the COVID-19 Crisis: Refocusing Teacher Presence and Learning Activity”.
Postdigital Science and Educcation, 2020 https://doi.org/10.1007/s42438-020-00155-y

[25] Hegarty, B., “Attributes of Open Pedagogy: A Model for Using Open Educational Resources”, Educational Technology, pp. 3-13, 2015.

[26] Chung, E., Noor, N. M., V. N. Mathew, “Are You Ready? An Assessment of Online Learning Readiness among University Students”, International Journal of Academic Research in Progressive Education and Development, Vol. 9, No. 1, pp. 301-317, 2020.

[27] Misman J., Sharipp M. T. M., Suryono S. S., S. Shaidin, "Islamic Perspectives: Using New Media in Education", International Journal of Academic Research in Progressive Education and Development, Vol. 9, No. 1, pp. 12-21, 2019.

[28] Chung, E., Subramaniam, G., L. Christ Dass, "Online Learning Readiness among University Students in Malaysia Amidst COVID-19”, Asian Journal of University Education, Vol. 16, No. 2, pp. 45-58, 2020.

[29] Isa, K, A. A. Latif, "Internet Browsing Trends among Malaysians during Movement Control Order (MCO) Period”, International Journal of Emerging Technologies in Engineering Research, Vol. 8, No. 4, 2020.

[30] Isabel Álvarez Cánovas , Carles Dulsat Ortiz , "Lessons Learned from a Distance Course: "More Use Could Have Been Made of It"," Universal Journal of Educational Research, Vol. 6, No. 9, pp. 1921 - 1927, 2018. DOI: 10.13189/ujer.2018.060910.

[31] McVay, M., “Developing a Web-Based Distance Student Orientation to Enhance Student Success in an Online Bachelor's Degree Completion Program. Unpublished practicum report presented to the Ed.D Program. Florida: Nova Southeastern University.

[32] Shafie, H., Abd Majid, F., I.S. Ismail, “Technological Pedagogical Content Knowledge (TPACK) in Teaching 21st Century Skills in the 21st Century Classroom”, Asian Journal of University Education, Vol. 15, No. 3, pp. 24-33, 2019

[33] Toquero, C. M., "Challenges and Opportunities for Higher Education Amid the COVID-19 Pandemic: The Philippine Context”, Pedagogical Research, Vol. 5, No. 4, 2020.

[34] Huang, R. H., Liu, D. J., Tlili, A., Yang, J. F., Wang, H. H., "Handbook on Facilitating Flexible Learning During Educational Disruption: The Chinese Experience in Maintaining Undisrupted Learning in COVID-19 Outbreak”, Beijing: Smart Learning Institute of Beijing Normal University, 2020.

[35] Yew O. F., M. Jambulingam, "Critical Success Factors of E-learning Implementation at Educational Institutions”, Journal of Interdisciplinary Research in Education, Vol. 5, No. 1, pp. 17-24, 2015.

[36] Garrison, D. R., N. D. Vaughan, "Designing Blended Learning to Create a Community of Inquiry in Blended Learning in Higher Education”, First Edition, San Francisco: Jossey-Bass Print, 2013, pp. 31-48. DOI: 10.1002/9781118269558.ch3

[37] Buhl, M., L. B. Andreasen, "Learning Potentials and Educational Challenges of Massive Open Online Courses 
(MOOCs) In Lifelong Learning”, International Review of Education, Vol 64, pp. 151-160, 2018. DOI: 10.1007/s11159-018-9716-z

[38] Phan, T. "Instructional Strategies that Respond to Global Learners' Needs in Massive Open Online Courses”, Online Learning, Vol. 22, No. 2, pp. 95-118, 2018 doi:10.24059/olj. v22i2.1160

[39] Angkana Tongpoon-Patanasorn, Cynthia White, "Teachers' and Students' Perceptions on Blended Learning in Tertiary English Language Courses: A Match?" Universal Journal of Educational Research, Vol. 8, No. 6, pp. 2455 - 2463, 2020. DOI: 10.13189/ujer.2020.080629.

[40] Malaysia Education Blueprint 2013-2025 (Preschool to
Post-Secondary Education), 2013, Ministry of Education Malaysia.

[41] Ulrich, C., A. Nedelcu, A. "MOOCs in Our University: Hopes and Worries", Procedia - Social and Behavioral Sciences, 180(November 2014), pp. 1541-1547, 2015. doi: 10.1016/j.sbspro.2015.02.304

[42] Islam, A. N., "Understanding E-Learning System Usage Outcomes in Hybrid Courses", 45th Hawaii International Conference on System Sciences, pp. 118-127, 2012. doi: 10.1109/HICSS.2012.613.

Hassanzadeh, A., Kanaani, F., S. Elahi, “A Model for Measuring E-Learning Systems Success in Universities”, Expert Systems with Applications, Vol. 39, No. 12, pp. 10959-10966, 2012. 